\title{
Towards a Framework to Integrate Facilities Management Cost Effective Parameters in Design Process
}

\author{
Rashidul Islam ${ }^{1}$ Sarajul Fikri Mohamed ${ }^{\# 2}$, Svein Bjørberg*3, Mohd Saidin Misnan4, Zakaria \\ Mohd Yusof ${ }^{5}$ \\ 1,2,4,5 Department of Quantity Surveying, Faculty of Built Environment, Universiti Teknologi Malaysia, \\ Skudai 81310, Johor Bahru, Johor, Malaysia \\ ${ }^{*}$ Department of Civil and Environmental Engineering, Norwegian University of Science and Technology \\ Multiconsult AS, Oslo, Norway \\ ${ }^{1}$ mrislam1080@gmail.com, ${ }^{2}$ sarajul@utm.my,335ein.bjorberg@ntnu.no, \\ ${ }^{4}$ b-saidin@utm.my, ${ }^{5}$ b-zyusof@utm.my \\ \#Corresponding Author e-mail: sarajul@utm.my
}

\begin{abstract}
Facilities management (FM) has a significant growth since last two decades as a new and exciting profession that embraces many essential parts of the built environment. Emphasis on early involvement of FM in the design stage to deliver of an efficient building; which is easy and cost-effective to maintain for the occupants. Present days, maintainability turn into foremost concern and unprecedented challenges for the project team as building projects are getting much more complex and difficult. However, lack of considering FM at early design phase has become a potential issue to increase the operation and maintenance budget, premature aging and dilapidation. Thus, this paper explores the consideration of direct involvement of FM knowledge and experience in early design is found useful for the improvement of cost effectiveness in long term perspective, and subsequently the aim of this paper to investigate the impact of design issues towards easily-maintainable building projects at post-occupancy stage and providing the actual avenues to integrate FM in design development process. Therefore, a critical analysis of the literature has been carried out to identify the potential errors of design at post occupancy stage. The paper critically analyses the current approach of building design; and explore the contributions of FM knowledge during the design phase. Based on the study of literature, it has been established that majority of the maintenance issues at using stage is design originated problems; mainly architectural, structural, mechanical, HVAC, and plumbing and sanitary. The involvement of the FM knowledge and experience at design process will contribute to reduce major repairs and alterations in the lifespan of the building.
\end{abstract}

Keyword - Facilities Management, Cost Parameters, Effectiveness, Design Process

\section{INTRODUCTION}

A holistic view of the topic facilities management (FM) has gradually developed as a new career over the past 15-20 years everywhere in the global and evolved into construction discipline since late 1980s [1]. It seems at reaching higher facility that is straightforward to run, maintain and manage. This new topic attempt to represent an elevated attention of the significance of the building operation and maintenance. This is avital part inside FM however the scope has emerged as broader and includes use of buildings in both the short and long term. FM is observed on the pre-operations level to peer how early involvement can create effective operations, reduce maintenance cost, end customers pleasure whilst also presenting higher facility that is good-looking and end user friendly. "FM at the design stage will add value to the facility by ensuring less "rework", emphasising value for money, efficient control of the team work". As a result, FM decisions in the early design stages of building projects are very important for enjoying long life better services in cost effective way. Numerous studies have attempted to explain that the early involvement of FM all through the design development and review stages on building project offers for avoiding the re-occurrence of design errors than also reduce the maintainability cost of building projects at post occupancy stage ([2], [3]).

Traditionally, design process is separated from construction, operation, maintenance, and facility services provision. Those detachment of design from the post design procedures create a number problem, for example, lack of constructability, operability, maintainability and serviceability, for designed facilities. In the most recent two decades, it is obvious that there been an expanding integration of design and construction in the developed country, like as U.K. construction industry[1]. Generally, there would two approaches about "integrating" design and construction, one is "design-build delivery method"[4], and another "early contractor involvement" in the process of design [5]. "Design-build practices” decrease constructability issues [6]. On the other study[7], 
"early contractor involvement" incorporates construction learning and experience into the design methodology so that project performance can be improved along with improvement of constructability.

Generally, in building development process different groups of individuals are included towards different phases for smooth progress of work. For an example, a consultant will be included with an extend starting with project briefing stage to handover stage, while a contractor is designated at the contract phase what's more proceeds up to post completion phase. To addition, there would numerous experts for example, such that architects, engineers, quantity surveyors, also different group of suppliers, contractors, and so on, who are appointed in different phases of a building project. In common way, in the accepted practice, these sets of individuals would not answerable after commissioning of building. Nevertheless, this finished building needs to be maintained adequately for its design existence. This part is assumed control eventually by a FM professional who will be named throughout alternately after commissioning of the building, in common practice.

A number of study conclusively revealed that, after commissioning of a building, the principle role of a FM personnel is the change of this physical item into a suitable, reasonable and habitable built environment for the owner and end user ([8], [9]). In particular, this condition should be maintained through the lifespan of building services. In this procedure, fruitful facility management reliably relies on the cost adequacy of its maintainability procedure. These "cost-effective" choices might be commenced from early design development stage for proficient maintainability of the facility ([10], [11]). Maintaining a building structure can turn into a costly and complex due to design complexity[12]. Furthermore, [13] and [14]concluded that these higher budgetary building cost components for maintenance have started from the early design development and construction phase.

However, in a published paper [15]described FM is typically thought to be a post construction service, and the contribution of FM as a key part of design process has regularly been absent or negligible, best case scenario. Different research endeavours have been made in the developed nation to investigate how to incorporate design outline with operation, facility maintenance, and service provisions. Subsequently, the significance of early FM integration has been perceived by researchers, professionals and practitioners. As indicated by [16], managing the building in proper way is the core responsibility of the FM-both their building facilities as well as services-and subsequently there is a need to support more prominent attention on applying their ability to building design. Correspondingly, [17]stated that FM ought to figure out how to function with architects and designer and the other way can better fulfil customers and end user's expectations.

Previously FM was considered as caretaking job like old fashion, moving around the office with repairing tools, supervising the renovation works and monitoring the level of cleanliness. However, interestingly, this is contrary to a study conducted by [18], FM has recently moved from "the boiler room to the board room" and represents a Fig. 1 shift of FM from 1900s to present. In a different study, [19] examined FM should represents both in operational and strategic levels. Several studies provide in-depth analysis of the work of FM integration and highlights the FM should be introduced at the early design development phase of building project rather than being called upon at the commissioning and post occupancy stages([14], [1] and [20]).

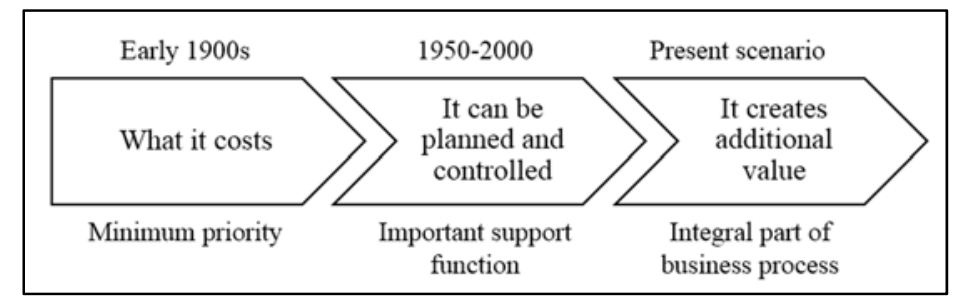

Fig. 1: Paradigm shift in facility management[18]

In-depth analysis of work revealed that, in the construction industry early maintainability issues was not measured as typical practice, until recent[11]. This has been heightened various maintainability issues of the building projects. Along these lines, in a different study [1], highlighted that FM integration within the project design process to decrease such potential maintainability problem which thus curtail the maintenance cost in effective way. Furthermore, in another study[21] demonstrated that FM has next to no control (i.e. around 4\%) amid the phase of post occupancy to decrease maintainability issues and flaws happening from design errors, while designer can take control (i.e. around 84\%), over the minimization of these issues, with the support of FM.

Reference [22] argued that integration of FM knowledge and experience at the early phase of the design process would upgrade the execution of the building projects and has been recognised as an appropriate proficient to sustainable building project. On the other way, FM is in a vital position to oversee each and every action in design process and enhance the co-ordination of different group in project development [23].Integration of FM in design process is mostly connected with FM knowledge and subsequently optimize the estimation of FM value in all phases of the design phase. However, recent developments in FM have 
heightened the need for identifying the critical issues that control FM from representing FM value in the strategic level of the design process.

So, maintainability need for lifetime of a typical building and those needs be more effectively addressed (reduced/eliminated) at design stage and have to find an approach for a particular building be evaluated in respect of building's maintain ability. This paper attempts to provide a more detailed investigation regarding the process of setting up a framework of cost effective parameters for integrating FM in design process to ease maintainable project that will be favourable FM professionals and different experts in the design team, also guides for a better understanding of cost parameters towards the obtaining of easily-maintained facilities through reducing the extent of maintenance cost issues that would possibly occur during the post-occupancy stage. Without a doubt, these study endeavours have added to the support of early FM inclusion all through the building design process.

\section{ReSEARCh MethodologY}

To achieve the cost-effective design parameters from the operation and maintenance phase to the design development team, the researcher has carried out numerous research related activities, including:

- Addressing the substantial role of FM all over the life cycle of the building project

- For figuring out the effects of design error cost on post occupancy phase an important literature overview was conducted.

- Current building projects design method critically analysed.

- Exploring the FM contribution throughout the design process and facilities operation and maintenance.

Furthermore, wide-ranging literature review includes a widespread note receiving of any feasible references according to get the cost saving parameters, based totally on the conceptual evaluation approach. Since, as mentioned previously, there has been lack of studies on maintainability cost increasing element due to design errors that is deemed necessary for project development stage. For the purpose about figuring out the factors, applicable articles containing mention because of analysing into depth. This portion of the evaluation involved "differentiating and combining” the evidence collected[24].Importance was placed over which means regarding the phrases and not on the words itself. Henceforth, entire the recognized factors will be sorted in like categories no matter its description. This will be taken the use of "inductive coding technique". The methodology portion additionally concerned the approach of getting ready qualitative information. As the aim of this study is to understand in deepness the various cost parameter identified by researchers out of a variety of field, therefore appropriate approach used to be content analysis. Content analysis is the just frequent approach when analysing texts[25].Therefore, this study also looked-for references to fulfilment factors without identifying so.

\section{A. Data Collection Procedures}

The data collection section for literature analysis concerned an in-depth inquire of dense foremost journals consisting of however not restrained to, as outlined below:

- Architecture Science Review

- Building and Environment

- Building Research and Information

- Engineering Construction and Architectural Management

- Jordan Journal of Civil Engineering

- Journal of Civil Engineering and Management

- Journal of Construction Engineering and Management

- Science and Technology for the Built Environment

Other than the mentioned above, the subsequent databases additionally have been searched; Emerald, Web of Science, ASCE Online Library, Science Direct in addition Taylor and Francis Online. Collectively, many more journals be situated according to the field from above mentioned database.

Furthermore, for searching used keywords were identified by authors preliminary literature review. Also, the articles were choice from journals to that amount had been peer-reviewed or else scholarly. However, the proper decision of the articles used to be based about the researcher's choice since analysing the article abstract then title. Prospective articles will be prioritized if contain some records indicating the research related cost factor.

\section{EFFECTS OF DESIGN ON FACILITY OPERATION AND MAINTENANCE}

Facilities operations and maintenance covers all that wide range of services required to ensure that the built environment will accomplish the jobs for built and designed facilities. Previous research conclusively been shown that operations and maintenance commonly incorporates the everyday events vital for the building and its frameworks and equipment to accomplish their proposed jobs[26]. Expansion of operation and maintenance cost can be credited to inadequate design[27].The Building Research Establishment in England directed an overview 
of building failure pattern and their interference and found that 58 percent of the imperfections have started from defective design[28]. Defects in building design put a tremendous load on the working for whatever remains of its next operational life and no compensation can fulfil this one. In such circumstances, $[29,108]$ demonstrated the responsibility cannot be ignored by the respective designer.

In any case, it appears that the designer is constantly free from any of his design related errors once the building has been finished and given the authentication for resident using. Only the worst cases, the designer must be sued if a noteworthy mishap happens, or the major failure happens in building subsequently of the designer carelessness. Another study [30]attempted to describe that "architects in the United States have historically been bound by comprehensive legal requirements and responsibilities for the building design. They are legally obligated to safeguard the public health, safety, and welfare”. In addition, architects need to provide great emphasis to produce fruitful designs for their client through inputs of the building systems.

Significance of such expert collaboration would strengthening the design output in the design method[31]. Consistent with above findings [27]indicated that, arrangement of satisfactory structural design, enlisting of qualified architects and design practitioners, and arrangement of adequate points of interest in construction drawings could be enhanced building maintenance system. As shown in Fig. 2, after getting the guideline from decision and briefing phase the conceptual set of drawings is prepared by the architectural design team. Then, these drawings are headed to the other professional members of the design team for various input. Thereafter integrated FM check the maintainability of the combined output from the others design team members through his accumulated experience from facility operation and maintenance. If it fulfils the maintenance criteria, then it submitted for final draft by the architect, or otherwise, it sends back to the respective professionals for further modification. While FM show, the positive response regarding maintainability criteria, the integrated design output passes to the architectural design team for final working drawing and to be continued at construction stage. Some concerns raised about maintainability, that impacts of the choices made amid the plan stage would have extensive consequences for future building maintainability cost[32].

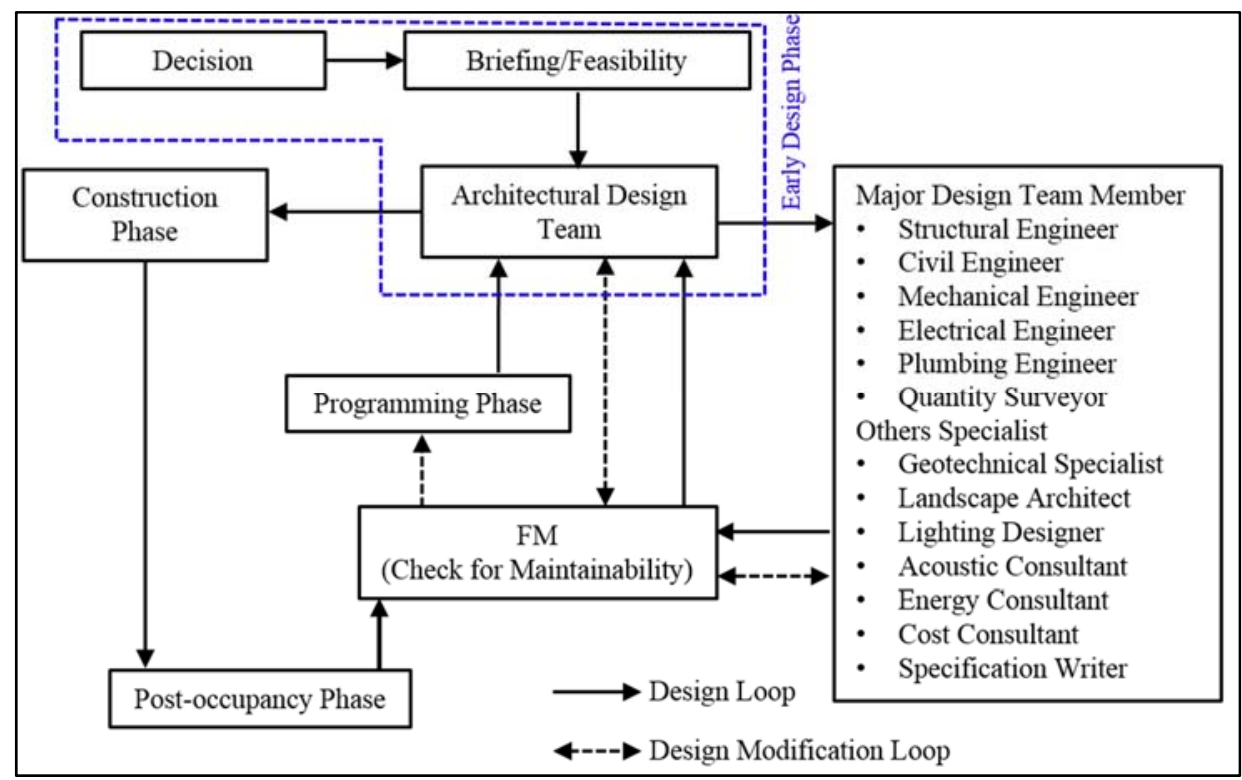

Fig. 2: Design modification flow in integrated design team [33]

Making arrangements for maintenance should be started during design stage and proceed all through the life-span of the building. These days, FM faced large number of continuous and expensive building performance issues at the post-construction stage for operation and maintenance. Previous studies attempted to explain that the decision adopted in planning and design development phases have a substantial cost effect on the future performance of the building throughout of the design life ([21],[31]). The suggested feedback from the FM group to the integrated design team assists to escape redundancy of operation and maintenance issues that happen amid the useful building design life.

Quality of design and construction decisions are main contributor for measuring the building performance. According to [34] shortfall in the building performance originated from inadequacies in design and construction which great reflection can be observed on the maintenance level of building design life. Building life cycle depends on the two vital criteria "design and maintenance" of building process is analysed by [35].By reducing design and construction defects substantial amount of maintenance expenses can be decrease [36]. Building maintainability cost positively and negatively affected by design decision made at design stage. In this manner, 
there is a need to consider potentials of FM at the design phase to avert unplanned maintenance cost during post occupancy.

\section{Importance of INTEgrating FM Decisions at EARLy Design Phases}

The life cycle of a construction project can be broken down into seven major phases was investigated by [37] and [1] and stated "inception, through briefing and feasibility, design, tender and construction preparation, construction, commission and handover, to occupancy that covers operation, maintenance, and services provision represented by the FM profession". "Inception, briefing/ feasibility, and design" are threesome commonly considered as early design phase as shown in Fig. 2.

Key strategy of FM is concentrated on comfort to the building occupants at affordable and reasonable budget. The relationship between FM and design phase has been widely investigated that if FM introduces during the early design phase, the so-called "proactive" FM can get the general control towards taking right choices for cost effective maintainability approaches[38]. FM experts enriched with their immense store of practical skill and experience and receive the operational and maintenance opinion from end users, are phenomenal contributions for the design professionals to develop "highly maintainable" buildings. In this manner, FM could be the "pathway" for giving such opinion and for persuading designer to choose appropriate design decision to make life comfortable for all stakeholder.

According to an investigation of Project Management Institute (PMI), compared with a post occupancy phase, the level of instability, threat and shareholder impact at early stage is substantially higher, but cost for changes during early stage is much lower ([39],[5]).

Reference [40] has demonstrated that most choices are made during the early design phase and they affect later phase, for example construction and post-construction. In addition [41]presented a comprehensive review that "briefing provides strategic decisions, whereas design provides technical decisions and early design phase links strategic and technical decision". Construction contractor and FM can be included during early design stage to stay away from improper design decisions[7]. FM comments highlight mistakes and failures of previous design and give motivation to the designer for more errors free design generation[42].

\section{Consideration of Cost Effective Parameters in Design Phase}

In the process of applying cost-effectiveness in maintenance cost of building facilities at design phase activities or elements assume an essential part. Generation of cost effective maintenance management method, need to identify most vital components or activities from maintenance cost analysis. From various facilities use and user ought to choose most relevant and basic element in considering cost- effective way. Appropriate facilities maintenance cost variables in design phase are identified based on critical review from available literature in the building maintenance.

One study [43]identified eleven factors in three major groups that directly or indirectly involve in maintenance cost: design (civil, architectural, maintenance priority), person (consultant, contractor) and construction (drawing, materials, equipment, and specification). Apart from design and construction quality, [44]stressed external factors such as weather, surrounding environment, site ground condition ,and chemical effect. Building life cycle cost can be broken down as shown Fig. 3. At first level describes capital cost, operation cost, FM cost, renovation cost and disposal cost. Than FM cost elements classified into building system and non-building system. This building system elements include building frame, mechanical and electrical. Other studies broadly classified this involvement under design, construction, and maintenance knowledge ([21],[32]).

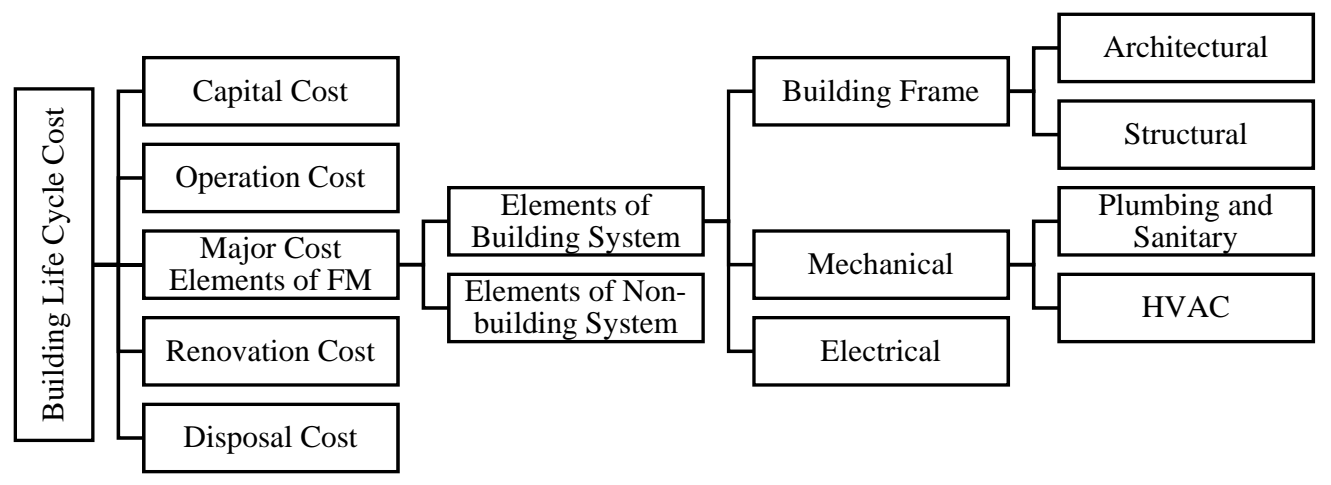

Fig. 3: Cost components of FM ([45], [46])

According to relevant research study by [47] also found the following issues that heavily affect the building maintenance cost: existing structures, lack of contract and specifications details, climate, short time period, communication gap, inactiveness of all stakeholder, and lack of practitioners. Furthermore, includes related to 
knowledge and experience: building location and shape, duration of response, types of repairing work, selection of materials and techniques, Contractors' and suppliers' particulars, previous cost data, health and safety issues[48].A recent study [49]reviewed the literature from the period and described eighty four number factors affecting the building maintenance cost, summarised in eight major groups: project management, quality, participants in project, environment and site, time frame, monetary, health and safety and lastly others. Surveys conducted by [50]have shown that sanitary, electrical and safety and health issues are top three priority preference in maintenance work.

Major contributing factors for the building maintenance have been identified by [51,108]design, materials and workmanship. Design issues include architecture, cracks or collapse originate from structural fault, mechanical electrical plumbing including acoustic, ventilation and fire protection. Stressed other factor such as lack of supervision and corruption. Previous study has pointed to some of the ways in which fifteen common maintainability issues were observed that increase the maintenance budget, among them water seepage lack of waterproofing errors was the most common[14]. Another twenty-six significant factors were established that commonly related at design phase and discussed with six major groups as listed: future maintenance necessities, involvement of FM in the design phase, availability of future maintenance, consider weather condition, consider future maintenance cost and adequate drawing detailing.

A recent study included defects generating from design phase and construction phase influence the building maintenance cost[52]. Eleven design factors and sixteen construction factors are identified at design phase and construction phase respectively. He discovered faulty construction materials, lack of supervision, inadequate drawing specifications, short of quality control, architectural design defects[53]and ignoring maintainability issues at the design stage are the topmost issues affecting maintenance cost at post construction phase.

FM would be face operability problem at post occupancy phase while a building project continues without having sufficient integration of design and operations planning, asserted by [54]. Previous one study has reported the detail of common design issues and operational issues at maintainability phase which could be resolved by integrating FM participation during early design phase[16]. These issues can be categorised the following major sub- headings as illustrated in Fig. 4:

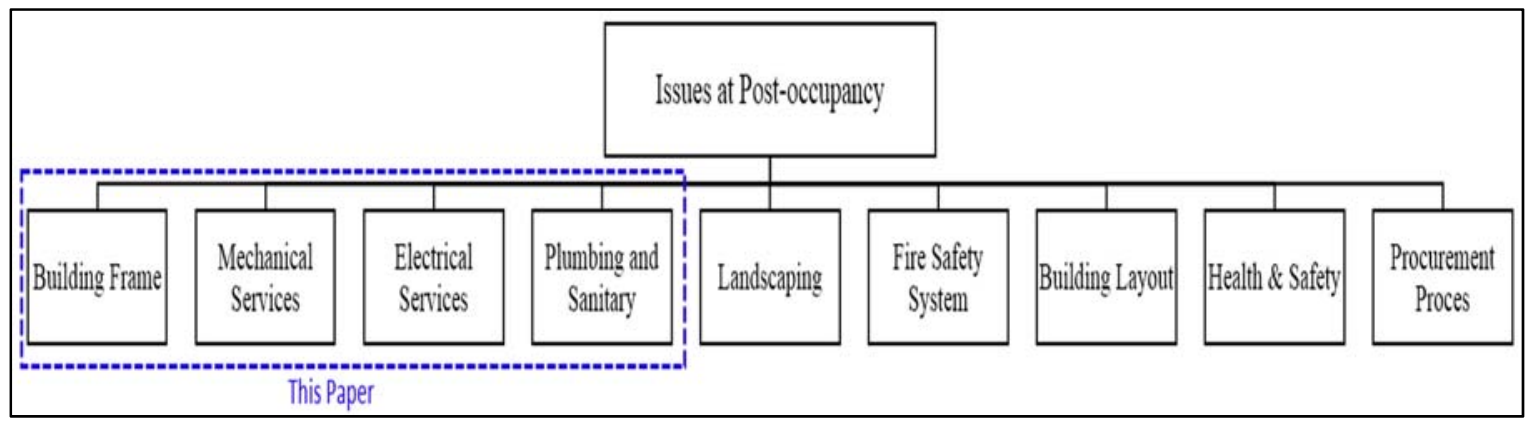

Fig. 4: Common operational issues ([54],[16])

In conclusion, FM would be face operability problem at post occupancy phase while a building project continues without having sufficient integration of design and operations planning. The summary of design related factors affecting the building maintenance cost identified through literature review is classified into 5 groups present in the following tables. Table I is illustrated architectural design related issues, Table II explained structural design related issues. While Table III explained electrical design related issues, Table IV illustrated mechanical design related issues, besides that Table V clarified HVAC design related issues.

\section{COMMON DESIGN ISSUES TO INCREASE MAINTENANCE COST}

Table I Architectural Design Related Issues Affecting Maintenance Cost

\begin{tabular}{|c|c|c|c|c|c|c|c|c|c|c|c|c|c|c|c|c|c|c|c|c|c|c|c|c|c|c|c|c|c|c|}
\hline & Architectural Design Issues & $\sqrt{\mathrm{E}}$ & 员 & 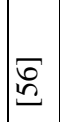 & 氙 & $\infty$ & $\Xi$ & & $\mid \begin{array}{l}\vec{E} \\
\vec{\Xi} \\
\vec{\Xi}\end{array}$ & & $\overrightarrow{\underline{\theta}}$ & $\widetilde{\widetilde{\sigma}}$ & $\overline{\tilde{\theta}}$ & 它 & 등 & $\overline{\mathscr{\theta}}$ & & & 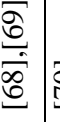 & $\stackrel{2}{2}$ & $\Xi$ & & & & & & & & & \\
\hline 1 & $\begin{array}{l}\text { Incomplete working drawing } \\
\text { and specification }\end{array}$ & & & & & & & & $\checkmark$ & & & & $\checkmark$ & & & & & & $\checkmark$ & $\checkmark$ & & & & $\checkmark$ & & & & & $\checkmark$ & \\
\hline 2 & $\begin{array}{l}\text { Inadequate working drawing } \\
\text { details }\end{array}$ & & & & & & & & $\checkmark$ & & & & $\checkmark$ & & & & & & $\checkmark$ & $\checkmark$ & & & & $\checkmark$ & & & & & $\checkmark$ & \\
\hline 3 & $\begin{array}{l}\text { Inability to maintain vertical } \\
\text { riser for service shaft }\end{array}$ & & & & $\checkmark$ & & & & $\checkmark$ & & & & & & & & & & & & & & & & & & & & & \\
\hline 4 & $\begin{array}{l}\text { Signs of stains and seepage } \\
\text { around windows }\end{array}$ & & & & $\checkmark$ & $\checkmark$ & & & & & & $\checkmark$ & & & & & & & & & & & & & & & & & & \\
\hline
\end{tabular}


5 Specification of bellow-

5 standard quality tiles

6 Chipping around sharp wall

6 edges

7 Non-availability of specific

7 building materials in market

8 In appropriate selection and

specification of materials

Difficult to reach and maintain

fenestration

10 Plaster decay on external wall

10 lurface

11 Moisture and vapours pass

11 through

Hard to move furniture and

12 equipment due to the limited width and height of doors

Unpleasant odour transmit due

13 to inappropriate position of kitchen and toilets

14 Positioning of large window at

14 elevation for solar

15 Signs of stains visible lack of

15 ventilation

Paint peeling, flaking,

16 blistering, biological attack and efflorescence

17 Specify dark colour paint as an exterior finish

18 Building shape and orientation

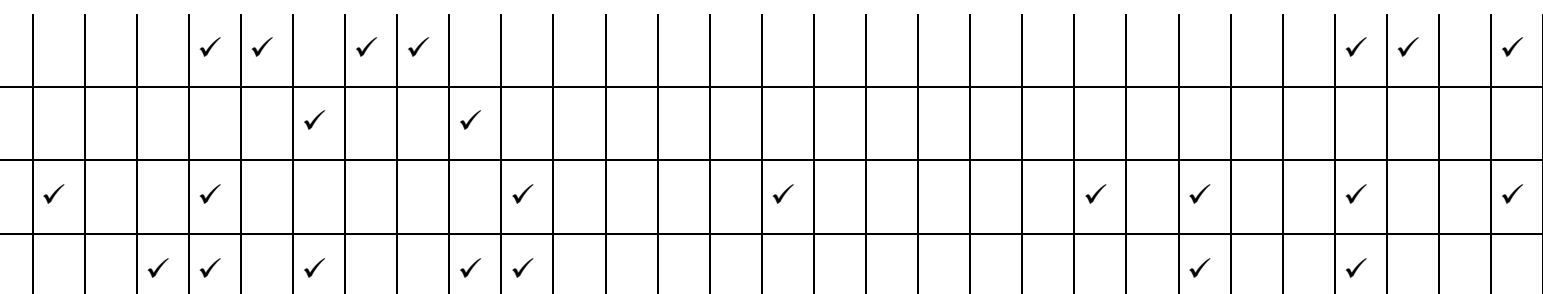

\begin{tabular}{l|l|l|l|l|l|l|l|l|l|l|}
$\checkmark$ & & $\checkmark$ & & & & & & & \\
\hline
\end{tabular}

\begin{tabular}{ll|l|l|l|} 
& & & & $\checkmark$ \\
\hline
\end{tabular}

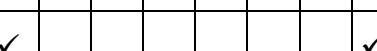

\begin{tabular}{ll|l|l|l|}
\hline & & & \\
\hline & & & $\checkmark$
\end{tabular}

\begin{tabular}{ll|l|l|l|l|l} 
& & & & $\checkmark$ & \\
\hline$\checkmark$ & & & & & \\
$\checkmark$ & & & &
\end{tabular}

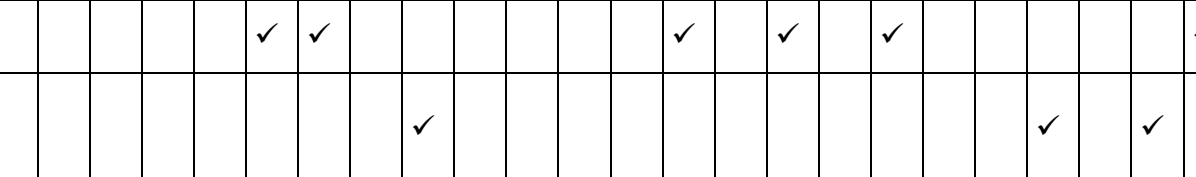

$\checkmark$

\begin{tabular}{|l|l|l|l|}
\hline & & \\
\hline & &
\end{tabular}

$\checkmark$

\begin{tabular}{l|l|l|l|l|} 
& $\checkmark$ & & \\
$\checkmark$ & $\checkmark$ & & $\checkmark$
\end{tabular}

\begin{tabular}{ll|l|l|} 
& & \\
$\checkmark$ & & \\
\hline & $\checkmark$ &
\end{tabular}

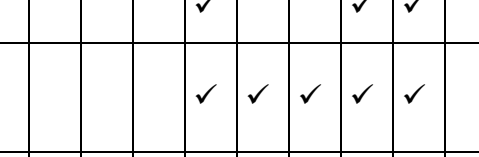

\begin{tabular}{lll|l|l|l|l|l|}
\hline & & & & & & & \\
\hline & & & & & & & \\
\hline
\end{tabular}

\begin{tabular}{l|l}
$\checkmark$ & $\checkmark$
\end{tabular}

From Table I among all architectural design issues, the most important challenge is "non-availability of specific building materials in market" when replacement is required at post occupancy phase. After that following three challenges, costly and substantial interruption to the smooth operation, are (1) specification of bellow-standard quality tiles, (2) inappropriate selection and specification of materials, and (3) paint peeling, flaking, blistering, biological attack and efflorescence. Moreover, among the category (1) incomplete working drawing and specification, (2) inadequate working drawing details, (3) moisture and vapours pass through, and (4) signs of stains visible lack of ventilation are next important challenge that increase unanticipated maintenance cost.

Table II Structural Design Related Issues Affecting Maintenance Cost

\begin{tabular}{|c|c|c|c|c|c|c|c|c|c|c|c|c|c|c|c|c|c|c|c|}
\hline & Structural Design Issues & $\widehat{\Xi}$ & 员 & 点 & $\overline{\widetilde{d}}$ & $\stackrel{\infty}{\triangle}$ & $\bar{\Xi}$ & 吕 & $\Xi$ & $\exists$ & $\overline{\tilde{\theta}}$ & 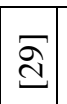 & $\Phi$ & פ & $\underline{n}$ & $\begin{array}{c}\sqrt{2} \\
\tilde{\omega}\end{array}$ & 尽 & 足 & $\underset{\Xi}{\mathbb{E}}$ \\
\hline 1 & $\begin{array}{l}\text { Plaster crack at joint i.e. concrete-brick } \\
\text { joints and wall-floor joints }\end{array}$ & & $\checkmark$ & & & & $\checkmark$ & $\checkmark$ & $\checkmark$ & & $\checkmark$ & & & & & $\checkmark$ & & & \\
\hline 2 & $\begin{array}{l}\text { Damaged underground pipes line due to } \\
\text { ground settlement }\end{array}$ & & $\checkmark$ & & & $\checkmark$ & & $\checkmark$ & & & & & & & & & $\checkmark$ & & \\
\hline 3 & $\begin{array}{l}\text { Inadequate concrete cover causes rebar } \\
\text { corrosion }\end{array}$ & & & $\checkmark$ & $\checkmark$ & & & $\checkmark$ & & $\checkmark$ & & & & & & & & & \\
\hline 4 & $\begin{array}{l}\text { Differential settlement generates cracks in } \\
\text { floor slabs, walls, and tiles }\end{array}$ & & & $\checkmark$ & & & $\checkmark$ & & $\checkmark$ & & & & & & & & & & \\
\hline 5 & Uncommon design and technology & & & & & & & & & & & & & & & $\checkmark$ & $\checkmark$ & $\checkmark$ & $\checkmark$ \\
\hline 6 & $\begin{array}{l}\text { Tile cracks, failure and fraction at fragile } \\
\text { points }\end{array}$ & & & $\checkmark$ & & & $\checkmark$ & $\checkmark$ & & & & $\checkmark$ & & & & & & & \\
\hline 7 & $\begin{array}{l}\text { Moisture and dirt infiltration through } \\
\text { expansion joints }\end{array}$ & & $\checkmark$ & & & & $\checkmark$ & & & & & & & & & & & & $\checkmark$ \\
\hline 8 & $\begin{array}{l}\text { Moisture penetration at beam-wall joints, } \\
\text { walls, and ceiling-wall joints }\end{array}$ & & $\checkmark$ & $\checkmark$ & & & & $\checkmark$ & & & & & & & & & & & \\
\hline 9 & Cracks in columns and beams & $\checkmark$ & & $\checkmark$ & & & & & & $\checkmark$ & $\checkmark$ & & & & & & & & \\
\hline 10 & Short time frame for design preparation & & & & & & & & & & & & $\checkmark$ & $\checkmark$ & $\checkmark$ & & $\checkmark$ & & \\
\hline 11 & Inadequate structural design & & & & & & & & & & & & & & & $\checkmark$ & $\checkmark$ & & $\checkmark$ \\
\hline 12 & Inaccurate geotechnical investigation & & & & & & & & & & & & & & & $\checkmark$ & & & $\checkmark$ \\
\hline
\end{tabular}


Table II demonstrate that "plaster crack at joint i.e. concrete-brick joints and wall-floor joints" is most challenging issues among all structural design related issues, would require costly repairs. The second most important issues is "uncommon design and technology" and followed by issues (1) damaged underground pipes line due to ground settlement, (2) inadequate concrete cover causes rebar corrosion, (3) tile cracks, failure and fraction at fragile points, (4) cracks in columns and beams, and (5) short time frame for design preparation. These challenges would eliminate or reduce by integrating FM knowledge at design phase.

Table III Electrical Design Related Issues Affecting Maintenance Cost

\begin{tabular}{|c|c|c|c|c|c|c|c|c|c|c|c|c|c|c|c|c|c|}
\hline & Electrical Design Issues & ळ & $\vec{\varpi}$ & $\begin{array}{l}\nwarrow \\
\infty \\
\infty\end{array}$ & 든 & 只 & ఐ & Ð & 吕 & হ & $\underset{0}{\mathscr{0}}$ & $\widehat{\widehat{\infty}}$ & 我 & 㿝 & ஓ & 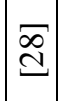 & $\bar{\sigma}$ \\
\hline 1 & Exposed electrical cabling and loose connections & $\checkmark$ & & $\checkmark$ & & $\checkmark$ & $\checkmark$ & & & & & & & & $\checkmark$ & & \\
\hline 2 & Exposed plugs at open and wet places & $\checkmark$ & & & & $\checkmark$ & & & & & & & & & $\checkmark$ & & \\
\hline 3 & Short circuits in plug points & $\checkmark$ & $\checkmark$ & $\checkmark$ & $\checkmark$ & $\checkmark$ & & & & & & & $\checkmark$ & $\checkmark$ & & & \\
\hline 4 & Absence of grounding systems & $\checkmark$ & & & & $\checkmark$ & & & & & & & & & & & $\checkmark$ \\
\hline 5 & Total power cut-off while fire & & & $\sqrt{ }$ & & & & & & & $\checkmark$ & & & & & & \\
\hline 6 & $\begin{array}{l}\text { Convergence of low voltage cabling with high } \\
\text { voltage cabling in the same ducts }\end{array}$ & $\checkmark$ & & & & & & & & & & & & & & & \\
\hline 7 & $\begin{array}{l}\text { Inappropriate placement for main boards and } \\
\text { circuit breaker }\end{array}$ & $\checkmark$ & & & $\checkmark$ & $\checkmark$ & & & $\checkmark$ & & & $\checkmark$ & & $\checkmark$ & & $\checkmark$ & \\
\hline 8 & Total power cut as of one fault & $\checkmark$ & & & $\checkmark$ & $\checkmark$ & & & & & & $\checkmark$ & & & & & \\
\hline 9 & Inadequate number and distribution of plug points & $\checkmark$ & $\checkmark$ & & $\checkmark$ & & & $\checkmark$ & & & & & & & & & \\
\hline 10 & Incorrect Placement of light switches & $\checkmark$ & & & & & & & & & & & & & & & \\
\hline 11 & Flickering and blinking of fluorescent lamps & $\checkmark$ & & & $\checkmark$ & $\checkmark$ & & & & & & & & & & & \\
\hline 12 & $\begin{array}{l}\text { Difficulties to reach high ceiling locations } \\
\text { changing and cleaning fused light bulbs }\end{array}$ & $\checkmark$ & & & $\checkmark$ & & & & & $\checkmark$ & & & & & & $\checkmark$ & \\
\hline
\end{tabular}

As illustrated in Table III, top three challenges are "exposed electrical cabling and loose connections", "short circuits in plug points", and "inappropriate placement for main boards and circuit breaker", these issues might potential damages to the electrical equipment, thus imposing expensive repair works.

Table IV Plumbing Design Related Issues Affecting Maintenance Cost

\begin{tabular}{|c|c|c|c|c|c|c|c|c|c|c|c|c|c|c|c|}
\hline & Plumbing Design Issues & $\bar{\sigma}$ & 氜 & $\begin{array}{l}\infty \\
\stackrel{\infty}{\varrho} \\
.\end{array}$ & $\stackrel{\widetilde{v}}{\tilde{\omega}}$ & $\stackrel{\infty}{\perp}$ & $\bar{\Xi}$ & 觞 & $\Xi$ & $\Xi$ & $\tilde{\widetilde{\theta}}$ & & & & 号 \\
\hline 1 & Inability to reach and maintain pipelines & & $\checkmark$ & & $\checkmark$ & $\checkmark$ & & & & & & $\checkmark$ & & & \\
\hline 2 & $\begin{array}{l}\text { Interrupt water supply during maintenance due to absence of } \\
\text { shutoff valves }\end{array}$ & & & & & $\checkmark$ & & & & & & $\checkmark$ & & & \\
\hline 3 & Unable to reach sewer line for maintaining & & & & $\checkmark$ & $\checkmark$ & & & $\checkmark$ & & & & & & \\
\hline 4 & Corrosion of cast iron pipes & & $\checkmark$ & & $\checkmark$ & & & $\checkmark$ & & & & $\checkmark$ & & & \\
\hline 5 & Lack of ventilation vents propagate unpleasant odour & & $\checkmark$ & & $\checkmark$ & $\checkmark$ & & & & & & $\checkmark$ & & & \\
\hline 6 & Water leakage through walls or floors & & $\checkmark$ & & $\checkmark$ & & & $\checkmark$ & $\checkmark$ & & $\checkmark$ & & & & $\checkmark$ \\
\hline 7 & Water ponds on roofs lack of proper drainage system & & & & $\checkmark$ & & & & & $\checkmark$ & & $\checkmark$ & $\checkmark$ & & \\
\hline 8 & $\begin{array}{l}\text { Insufficient water supplies due to the inappropriate diameter of } \\
\text { pipelines and head pressure }\end{array}$ & $\checkmark$ & $\checkmark$ & & & & & & & & & & & & \\
\hline 9 & $\begin{array}{l}\text { Moulds growth and stains on the façade due to the use of external } \\
\text { drainage }\end{array}$ & & $\checkmark$ & & & & & & & & $\checkmark$ & & 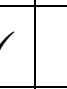 & & \\
\hline 10 & Insufficient diameter causes low sewer drainage & & $\checkmark$ & & & $\checkmark$ & & & & $\checkmark$ & & $\checkmark$ & & & \\
\hline & $\begin{array}{l}\text { Leakage through floor trap for improper waterproofing membrane } \\
\text { type }\end{array}$ & & & & & & $\checkmark$ & $\checkmark$ & $\checkmark$ & $\checkmark$ & & & $\checkmark$ & & $\checkmark$ \\
\hline 12 & $\begin{array}{l}\text { Noise and turbulent flow in pipelines caused by inadequate } \\
\text { diameter }\end{array}$ & & $\checkmark$ & & & $\checkmark$ & & & & & & & & & \\
\hline & $\begin{array}{l}\text { Fungi and moulds growth at bathtub edges because of improper } \\
\text { sealant type }\end{array}$ & $\checkmark$ & & & & & & $\checkmark$ & & & & & & & \\
\hline & $\begin{array}{l}\text { Signs of cracks in plaster or tiles because of suspended water } \\
\text { closets }\end{array}$ & & $\checkmark$ & & & & & $\checkmark$ & & & $\checkmark$ & & & & \\
\hline
\end{tabular}


Table IV provides "water leakage through walls or floors", "leakage through floor trap for improper waterproofing membrane type", and "insufficient diameter causes low sewer drainage" as the top most issues of plumbing design affecting maintenance cost.

Table V HVAC Design Related Issues Affecting Maintenance Cost

\begin{tabular}{|c|c|c|c|c|c|c|c|c|c|c|c|c|c|c|c|c|c|c|c|c|}
\hline & HVAC Design Issues & 导 & $\stackrel{\square}{\square}$ & 氙 & $\mathscr{\mathscr { E }}$ & 氜 & 泉 & 合 & $\stackrel{\infty}{\infty}$ & $\overline{\mathscr{O}}$ & $\sqrt{6}$ & 离 & 疍 & 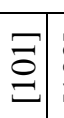 & & & $\begin{array}{l}\text { 守 } \\
\text { ( }\end{array}$ & & & \\
\hline 1 & $\begin{array}{l}\text { Shortfall of the HVAC system for comfortable } \\
\text { temperature }\end{array}$ & & & & $\checkmark$ & $\checkmark$ & $\checkmark$ & & & & $\checkmark$ & & & & & & $\checkmark$ & $\checkmark$ & & \\
\hline 2 & $\begin{array}{l}\text { Poor indoor air quality that may cause infectious } \\
\text { diseases and respiratory illnesses }\end{array}$ & & & & & & & & & & $\checkmark$ & & & & $\checkmark$ & & $\checkmark$ & & & \\
\hline 3 & $\begin{array}{l}\text { Overheating of the building during maintenance } \\
\text { and/or replacement }\end{array}$ & $\checkmark$ & $\checkmark$ & & & & & & & & $\checkmark$ & & $\checkmark$ & & & & & $\checkmark$ & & \\
\hline 4 & $\begin{array}{l}\text { Water spillage from HVAC units' absence of } \\
\text { condensation drainage systems }\end{array}$ & & & $\checkmark$ & & $\checkmark$ & & $\checkmark$ & & & $\checkmark$ & & & & & & & & 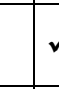 & \\
\hline 5 & $\begin{array}{l}\begin{array}{l}\text { Noisy air-handling units because of improper } \\
\text { insulation }\end{array} \\
\end{array}$ & & & & & $\checkmark$ & & & $\checkmark$ & & $\checkmark$ & $\checkmark$ & & & & & & & & \\
\hline 6 & $\begin{array}{l}\text { Inability to reach chillers, cooling towers and } \\
\text { condensers for maintaining }\end{array}$ & & & & & $\checkmark$ & & & & & $\checkmark$ & & & & & & & $\checkmark$ & & \\
\hline 7 & Stains on false ceilings caused by leaky HVAC ducts & & & $\checkmark$ & & $\checkmark$ & & $\checkmark$ & & $\checkmark$ & & & & & & & & & & \\
\hline 8 & Moisture condensation on walls and glass & $\checkmark$ & $\checkmark$ & & & $\checkmark$ & & $\checkmark$ & & & & & & $\checkmark$ & & $\checkmark$ & & & & \\
\hline 9 & $\begin{array}{l}\text { Overcooling of the building caused by temperature } \\
\text { fall during winter }\end{array}$ & & & & & & & & & & $\checkmark$ & & & & & & & & & \\
\hline
\end{tabular}

Table V indicates that "shortfall of the HVAC system for comfortable temperature", "water spillage from HVAC units' absence of condensation drainage systems", and "moisture condensation on walls and glass" are foremost issues in HVAC design phase, these design errors would require costly repairs during the service of buildings.

\section{CONCLUSION}

Early consideration of maintainability issues during the early design and review stages offer high level of comfort to end users, decreasing maintainability budgets plans, and in the end the life cycle expenses of the building project. This study attempts to investigate the impact of design issues towards easily-maintainable building projects at post-occupancy stage and providing the actual avenues to integrate FM in design development process. These design issues were synthesized upon review of the published international and national literature in the field of building system maintenance and professional practice. As the altering main structure and core services are difficult inherent at the life cycle of building usage period, it is feasible to consider probable design alteration at the early design stage with addressing all possible solutions. Thus, identified set of design issues in this paper may be considered by design professionals at design phase to eliminate, or at least reduce occurrence of unexpected maintenance issues as well as budget in buildings. Also, this study can be raised consciousness among all professionals in the built-environment community about the importance of the interaction and communication between the maintenance and design teams all the way through the design phase. Lastly, this study emphasizes on the significance of integrating FM experiences in the design phase in terms of decreasing cost involvement at building maintainability phase.

\section{REFERENCE}

[1] X. Meng, "Involvement of Facilities Management Specialists in Building Design: United Kingdom Experience," Journal of Performance of Constructed Facilities 27October pp, pp. 500-507, 2013.

[2] R. O. Agustsson and P. A. Jensen, "Building commissioning: what can Denmark learn from the U," S experience Journal of Performance of Constructed Facilities, vol. 26, no. 3, pp. 271-278, 2012.

[3] M. Hassanain, A. Al-Hammad, and F. Fatayer, "a., M., \& Assessment of defects in HVAC systems caused by lack of maintenance feedback to the design team," Architectural Science Review 8628June, pp. 1-8, 2015.

[4] A. Thomas, K. Design-build, U. Wiley-Academy, and C. West, 2006.

[5] D. Mosey, K. Wiley-Blackwell, and U. Oxford, "Early contractor involvement in building procurement: Contracts, partnering and project management," 2009.

[6] D. Arditi, A. Elhassan, and Y. C. Toklu, "Constructability analysis in the design firm," J Constr Eng Manage, vol. 128, no. 2 , pp. 117126, 2002.

[7] L. Song, Y. Mohamed, and S. M. AbouRizk, "Early contractor involvement in design and its impact on construction schedule performance," J Manage Eng, vol. 25, no. 1, pp. 12-20, 2009.

[8] J. Kelly, K. Hunter, G. Shen, and A. Yu, "Briefing from a facilities management perspective," Facilities Vol 23 Nos 7 pp, vol. 8 , pp. 356-367, 2005.

[9] T. Ventovuori, T. Lehtonen, A. Salonen, and S. Nenonen, "A review and classification of academic research in facilities management," Facilities pp, vol. 25, no. 5/6 , pp. 227-237, 2007. 
[10] M. Y. L. Chew and N. Silva, "De Maintainabil ity problems of wet area in high-rise residential building in Singapore," Building Research and Information pp, vol. 31, no. 1, pp. 60-69, 2003.

[11] N. Silva and M. Ranasinghe, "De and Maintain ability risks of condominiums in Sri Lanka," Journal of Financial Management of Property and Construction pp, vol. 15, no. 1, pp. 41-60, 2010.

[12] G. A. Yusuf, S. F. Mohamed, Z. M. Yusof, and M. S. Misnan, "Adoption of Standard Based Pricing Method for the Procurement of Mechanical and Electrical Engineering Services in Malaysia," in Proceedings of the World Congress on Engineering, 2013, vol. 1.

[13] A. Adejimi, "Poor building maintenance in Nigeria: Are Architects free from blames," in Being paper presented at the ENHIR international conference on "Housing: New challenges and innovations in tomorrow's cities" in Iceland, 2005.

[14] N. Silva, "De Promoting the facilities management profession in the project development phase of high-rise buildings in Sri Lanka," Built Environment Sri Lanka 9 3744, pp. 1-2, 2011.

[15] F. T. Edum-Fotwe, C. Egbu, and G. F. Gibb, "Designed facilities management needs into infrastructure projects: case from a major hospital," Journal of Performance of Constructed Facilities Vol 17 No 1, 2003.

[16] D. Jaunzens, D. Warriner, U. Garner, and A. Waterman, "Applying Facilities Expertise in Building Design," Construction Reserach Communication Ltd London, 2001.

[17] F. Duffy, "Design and facilities management in a time of change," Facilities, vol. 18, no. 10/11/12, pp. 371-375, 2000.

[18] E. P. Rondeau, R. K. Brown, P. D. Lapides, N. J. Hoboken, and M. John, "Facility \& Sons," 2006.

[19] L. Tay and J. T. L. Ooi, "Facilities management: a 'Jack of all trades'? Facilities, Vol. 19 No," pp, vol. 10 , pp. 357-362, 2001.

[20] M. Tucker and M. R. A. Masuri, "The rationale to integrate facilities management into the development process," Property Management, vol. 34, no. 4 , pp. 332-344, 2016.

[21] W. K. Chong and S. P. Low, "Latent building defects: Causes and design strategies to prevent them," J Perform Constr Facil 101061 ASCE20 213221, vol. 3, no. 213 , pp. 0887-3828, 2006.

[22] B. Wood, "The Role of Existing Buildings in the Sustainability Agenda," Facilities, vol. 24, no. 1/2 , pp. 61-7, 2006.

[23] C. P. Hodges, "A facility manager’s approach to sustainability," Journal of Facilities Management Vol 3 No pp, vol. 4 , pp. 312-324, 2005.

[24] M. B. Miles and S. Thousand, "A. M. Huberman. . Qualitative Data Analysis," CA, 1994.

[25] D. Silverman, A., and S. Thousand, "Doing Qualitative Research: Handbook. CA," 2000.

[26] D. Sapp, G. National, U. S. A. Sciences, and D. C. Washington, "Facilities Operation and Maintenance," Whole Building Design of Building, 2009

[27] A. Al-Hammad, S. Assaf, and M. Ai-Shihah, "The effect of faulty design on building maintenance," Journal of Quality in Maintenance Engineering, vol. 3, no. 1, pp. 1355-2511, 1997.

[28] H. Seda, M. A. Avon, and I. H. Seeley, Home repair that pays off: 150 simple ways to add value without breaking your budget, Adam Media, Building maintenance, 2nd Ed. 1987.

[29] N. H. Ishak, "A. H. Chohan, and A," Ramly Implications of Design Deficiency on Building Maintenance at Post Occupational Stage Journal of Building Appraisal, vol. 3, no. 2, pp. 115-124, 2007.

[30] J. Gabrielli, U. S. A. Science, G. National, and D. C. Washington, "Architecture. Whole Building Design of Building," 2010.

[31] A. Ramly, C. G. Ramsey, and H. R. Sleeper, A link between design and maintenance. 2008.

[32] M. Y. L. Chew, S. S. Tan, and K. H. Kang, "Building Maintainability-Review of State of the Art," Journal of Architectural Engineering United States of America, 2004.

[33] M. A. Mohammed and M. Hassanain, "Towards Improvement in Facilities Operation and Maintenance through Feedback to the Design Team," The Built Human Environment Review, vol. 3, no. 1990 , pp. 72-87, 2010.

[34] O. T. Femi, "Effects Of Faulty Construction On Building Maintenance," International Journal of Technology Enhancements and Emerging Engineering Research, vol. 2, no. 3, pp. 73-79, 2014.

[35] N. B. Kiong and Z. B. Akasah, "Analysis of building maintenance factors for IBS precast concrete system: a review," International Journal of Engineering Research and Applications, vol. 2, no. 6, pp. 878-883, 2012.

[36] F. Gatlin, "Identifying and managing design and construction defects," Construction Insight from Hindsight 5, 2013.

[37] S. Pryke, H. Smyth, K. Blackwell, and U. Oxford, "The management of complex projects: A relationship approach," 2006.

[38] L. A. Newton and J. Christian, "Impact of Quality on Building Costs," Journal of Infra structure Systems pp, pp. 199-206, 2006.

[39] P. A. Management and I. Newtown, Project Management Institute. 2008.

[40] E. Erdener, "Linking Programming and Design with Facilities Management," Journal of Performance in Constructed Facilities February pp Erlandson, pp. 4-8, 2003.

[41] P. Fewings, K. Francis, and U. Oxon, "Construction project management: An integrated approach, Taylor and," 2005.

[42] "Bröchner, J. . Integrated Development of Facilities Design and Services," Journal of Performance of Constructed Facilities 1, vol. 17, pp. 19-23, 2003.

[43] S. Assaf, A. Al-Hammad, and M. Al-Shihah, "M and Effects of Faulty Design and Construction on Building Maintenance," Journal of Performance of Constructed Facilities, vol. 23, no. 3, pp. 175-181, 1996.

[44] B. A. Richardson and F. N., "Defects and deterioration in buildings, E\& London," 1991.

[45] K. Yu, T. Froese, and F. Grobler, "A development framework for data models for computer-integrated facilities management," Automation in construction, vol. 9, no. 2, pp. 145-167, 2000.

[46] Y. Liu, "A forecasting model for maintenance and repair costs for office buildings," Concordia University, 2006.

[47] W. M. Edmond, P. C. Albert, and W. M. Daniel, "Lam, Chan, and Chan, . Benchmarking success of building maintenance projects," 2010.

[48] M. S. Misnan, S. F. Mohamad, Z. M. Yusof, and A. Bakri, "Improving Construction Industry Safety Standard Through Audit: SHASSIC Assessment Tools for Safety."

[49] B. Akasah, H. M. R. Alriwaimi, and A., "Of Factors Affecting The Success Of Building Maintenance Projects," pp. 1-10, 2015.

[50] N. A. Yusof, S. Abdullah, S. Zubedy, and N. U. M. Najib, "Residents' maintenance priorities preference: The case of public housing in Malaysia," Procedia Social Behav Sci, vol. 62, no. 10 , pp. 508-513, 2012.

[51] N. Ahzahar, N. A. Karim, S. H. Hassan, and J. Eman, "A study of contribution factors to building failures and defects in construction industry," Procedia Engineering, vol. 20 , pp. 249-255, 2011.

[52] B. S. Waziri, "Design and construction defects influencing residential building maintenance in Nigeria," Jordan Journal of Civil Engineering, vol. 10, no. 3, pp. 313-323, 2016.

[53] H. Ismail and Z. M. Yusof, "Perceptions Towards Non-Value-Adding Activities During The Construction Process," in MATEC Web of Conferences, 2016, vol. 66, p. 00015: EDP Sciences.

[54] L. Cullen, "Human factors integration-Bridging the gap between system designers and end-users: A case study," Safety Science pp, vol. 45 , pp. 621-629, 2007.

[55] M. S. Al-Kafrawi, I. Maintenance, M.-a. Maintenance, and D. Saudi, "at King Fahad University of Petroleum and," 2011. 
[56] R. B. Aris and E. Universiti, "Maintenance Factors in Building Design," Master thesis Faculty of Civil Malaysia Malaysia, 2006.

[57] M. Y. L. Chew, Maintainability of Facilities for Building Professionals. 2010.

[58] M. Y. L. Chew, T. P. Ping. Staining of Facades. 2003.

[59] S. Das, M. Y. L. Chew, and F. Using, "Generic Method of Grading Building Defects to Improve Maintainability Decisions," Journal of Performance of Constructed Facilities, pp. 522-533, 2011.

[60] S. Fikri Mohamed and C. J. Anumba, "Potential for improving site management practices through knowledge management," Construction Innovation, vol. 6, no. 4, pp. 232-249, 2006.

[61] N. de Silva, M. F. Dulaimi, F. Y. Ling, and G. Ofori, "Improving the maintainability of buildings in Singapore," Building and Environment, vol. 39, no. 10, pp. 1243-1251, 2004.

[62] I. Flores-Colen, J. Brito, and V. P. Freitas, "De And De Stain in facades' rendering-diagnosis and maintenance techniques' classification, Construction and Building Materials, pp," vol. 22 , pp. 211-221, 2008.

[63] J. Georgiou, "Verification of a building defect classification system for housing," Structural Survey pp, vol. 28, no. 5 , pp. 370-383, 2010.

[64] S. Ghasson, "A low cost maintenance approach to high rise buildings," Journal of Facilities, vol. 23 , pp. 315-322, 2003.

[65] B. Hwang, S. R. Thomas, C. Haas, and C. Caldas, "Measuring the impact of rework on construction cost performance," J Constr Eng Manage, vol. 135, no. 3 , pp. 187-198, 2009.

[66] M. A. Hassanain and E. L. Harkness, "Priorities in building envelope design," J Archit Eng 101061ASCE 4 4751, vol. 2, no. 47 , pp. 1076-0431, 1998

[67] E. Harkness, M. A. Hassanain, and A. North, "Hailstorm and heat stress damage of membrane roofing in Saudi and Australia: Guidelines for service life," Archit Sci Rev, vol. 44, no. 3, pp. 211-220, 2001.

[68] P. E. D. Love, S. O. Cheung, Z. Irani, P. R. Davis, and Ieee, "Causal discovery and inference of project disputes," on Engineering Management, vol. 58, no. 3, pp. 400-411, 2011.

[69] P. E. D. Love, R. Lopez, J. Kim, and M. Kim, "Influence of organizational and project practices on design error costs," Journal of Performance of Constructed Facilities, vol. 28, no. 2 , pp. 303-310, 2014.

[70] M. H. Mousli and S. M. El-Sayegh, "Al \& Assessment of the design-construction interface problems in the UAE," Architectural Engineering and Design Management, vol. 12, no. 5, pp. 353-366, 2016.

[71] F. Mazarella, D. C. Washington, and D. Whole, "Interior Design Guide," National Institute of Building Sciences, 2011.

[72] I. Ofori, P. M. Duodu, and S. O. Bonney, "Establishing Factors Influencing Building Maintenance Practices : Ghanaian Perspective," Journal of Economics and Sustainable Development, vol. 6, no. 24 , pp. 184-193, 2016.

[73] B. Sugumaran and M. Lavanya, "Evaluation of design construction interface in construction industry," International Journal of Engineering Research Technology, vol. 2, no. 1, pp. 1-14, 2013.

[74] A. Sobotka and B. Thriene, "Sanitary Problem for Living Spaces and Health Risks Involved," Toxicology Letters, vol. 88, pp. 365$368,1996$.

[75] R. Talib, N. Zakaria, and M. Z. Sulieman, "Ahmad, a G," Assessment of Factors Affecting Building Maintenance and Defects of Public Buildings in Penang Malaysia Architecture Research, vol. 4, no. 2 , pp. 48-53, 2014.

[76] M. Y. L. Chew and S. S. Tan, "A multivariate approach to maintenance prediction of wet areas," Constr Manage Econ, vol. 22, no. 4 , pp. 395-407, 2004.

[77] N. Weshah, W. Ghandour, G. Jergeas, and L. Falls, "Factor analysis of the interface management (IM) problems for construction projects in Alberta," Canadian Journal of Civil Engineering, vol. 40, no. 9 , pp. 848-860, 2013.

[78] M. Chew, S. Das, N. De Silva, and F. F. Yee, "Grading maintainability parameters for sanitary-plumbing system for high-rise residential buildings," Proc BEAR2008: CIB Int. Con. on Bldg. Edu \& Res, 2008.

[79] R. Lopez and P. E. D. Love, "Design error costs in construction projects," Journal of Construction Engineering and Management, vol. 138, no. 5 , pp. 585-593, 2012.

[80] M. Alam, M. Maintenance, and D. Saudi, "Interview, maintenance engineer," King Fahd Univ of Petroleum and, 2011.

[81] K. Ashizawa, K. Omata, and E. Japan, "Property of ignition mechanism caused by thermal degradation on plug," Proc Annual Meeting of Japan Association for Fire Science and of Fire Science and Engineering Tokyo, pp. 386-389, 1997.

[82] V. Babrauskas, "How do electrical wiring faults lead to structure ignitions? Proc., Fire and Materials Conf," Interscience Communications London, pp. 39-51, 2001.

[83] J. Douglas and B. Ransom, Understanding building failures, 3rd Ed. 2007.

[84] "ECA (Electrical Contractor Association). . Adequate provision of electrical sockets outlets in the home, European Association of Electrical Contractors, Kortenberg, Belgium," 2014.

[85] M. K. Giridharan, I. K., and H. New, Electrical systems design: Data handbook, Publishing India. 2011.

[86] W. M. Kramer, Disaster planning and control. Fire Engineering Books, 2009.

[87] W. M. Kramer, O. K. Tulsa, A. Kusko, and M. B. Jacobs, "Disaster planning and control, PennWell Corporation, and The case of the faulty circuit breaker," Electr Constr Maintenance, vol. 99, no. 10 , pp. 20-22, 2000.

[88] R. Loyd and L. New, Master electrician's review: Based on the national electrical code 7th Ed. 2011.

[89] D. Marshall, D. Worthing, and R. Heath, "Understanding housing defects, Estates Gazette, London," 2009.

[90] U. S. Focus and D. C. Washington, "OSHA (Occupational Safety, and Health Administration). . "Electrical safety participant guide," Construction Safety and Health Dept of Labor, vol. 4 , 2014.

[91] P. Simmons and C. T. Stamford, Electrical grounding and bonding: Based on the national electrical code, 4th Ed. 2014.

[92] M. A. Hassanain, F. Fatayer, and A.-M. Al-Hammad, "Design phase maintenance checklist for water supply and drainage systems," Journal of Performance of Constructed Facilities, vol. 29, no. 3, p. 04014082, 2014.

[93] M. A. Hassanain, "Guidelines for the design of water and sewage systems in buildings," J Archit Eng 101061ASCE 11 117121, vol. 4, no. 117 , pp. 1076-0431, 2005.

[94] S. Y. Ahmed, I. Maintenance, and D. Saudi, "at King Fahd University of Petroleum and Minerals, November 21," Maintenance Department, 2011.

[95] S. A. Batterman, Hvac, A., and R., "H. Burge. . as Emission Sources Affecting Indoor Air Quality: Review." HVAC\&," vol. 1, no. 1 , pp. 61-78, 1995.

[96] I. M. Budaiwi, "An Approach to Investigate and Remedy Thermal-Comfort Problems in Buildings," Building and Environment, vol. 42, no. 5 , pp. 2124-2131, 2007.

[97] K. R. Grosskopf, H. Humid, and Ashrae, "P. Oppenheim, and T," Brennan Preventing Defect Claims in, vol. 50, no. 7 , pp. 40-52, 2008.

[98] C. M. Harris, A. G. Piersol, and N. Y. McGraw-Hill, Harris Shock and Vibration Handbook. 2002.

[99] R. S. Jones, Hvac, and Ashrae, "Controlling Noise from," vol. 45, no. 9 , pp. 28-34, 2003. 
[100]M. Liu et al., "J. Haberl. . Identifying and Implementing Improved Operation and Maintenance Measures in Texas Loan" Proceedings of the Study on Energy Efficiency In Buildings, Vol. . American Council for an Energy Efficient Economy," vol. 5 , pp. 153-165, 1994.

[101]J. W. Lstiburek and A., "of Cladding Problems Highlights the Need for a Holistic Approach to the Facility Design," Journal of Building Physics, vol. 19, no. 1, pp. 12-27, 1995.

[102]F. S. Merritt and J. Ambrose, Building Engineering and Systems Design. 1990.

[103]T. P. Ping, A. N. N., and B. National, "Maintainability of Facades in the Tropics: An for Maintainability Grading," Master thesis Department of of Singapore Singapore, 2003.

[104]A. K. Raza, Hvac, and D. Saudi, "I. M. Budaiwi. . Evaluation of Indoor Air Quality Status in Selected Commercial Buildings in Saudi Arabia: Role of the Proceedings of the 6th Saudi Engineering Conference, Vol. . King Fahd University of Petroleum and Minerals," vol. 1 , pp. 1129-1144, 2002.

[105]H. W. Stanford, Hvac, and C. R. C., Chillers and Cooling Towers: Fundamentals, Application, and Operation. 2012.

[106]I. Shirkavand and J. Lohne, "Lædre, O. . Defects at Handover in Norwegian Construction Projects," Procedia Social and Behavioral Sciences, vol. 226, no. 1877 , pp. 3-11, 2016.

[107]P. Thanaraju and H. M. Ali, "Important activities in activity-based life cycle cost in building facilities maintenance: A case study," Jurnal Teknologi, vol. 74, no. 2 , pp. 79-85, 2015.

[108]S. Bjørberg, A. Larssen, A. Temeljotov Salaj, and A. Haddadi, "Optimizing building design to contribute to value creation," in IPMA world congress 2015, 2015 